\title{
METALLO- $\beta$-LACTAMASE PRODUCING PSEUDOMONAS AERUGINOSA STRAINS ISOLATED IN HOSPITALS IN RECIFE, PE, BRAZIL
}

\author{
Vera Magalhães; Ana Kelly Lins; Marcelo Magalhães*
}

Departamento de Medicina Tropical, Centro de Ciências da Saúde, Universidade Federal de Pernambuco, Recife, PE, Brasil

Submitted: April 14, 2004; Returned to authors for corrections: March 21, 2005; Approved: May 10, 2005

\section{SHORT COMMUNICATION}

\begin{abstract}
Out of 24 nosocomial strains of Pseudomonas aeruginosa from Recife, Brazil, 15 (62\%) were metallo- $\beta$ lactamase producers. Such isolates were resistant to main antipseudomonas drugs, except polymixyn B and aztreonam. The enzyme responsible for the carbapenem-resistance belongs to SPM-1 class, and the gene involved, blaspm-1, is likely plasmid located.
\end{abstract}

Key words: Pseudomonas aeruginosa, multidrug-resistance, metallo- $\beta$-lactamase.

Since the early 1990 s, the therapeutic problem posed by multidrug-resistant Pseudomonas aeruginosa gained interest on the recognition of nosocomial strains capable to produce metallo- $\beta$-lactamase $(\mathrm{M} \beta \mathrm{L})$. The prevalence of these strains is increasing in different parts of the world $(3,9,11,16,18)$, including Brazil $(4,12,13,17,19)$.

$\mathrm{M} \beta \mathrm{L}$ enzymes are a cause of concern because they are able to hydrolyze most beta-lactams, including imipenem and meropenem, drugs considered of reserve for the treatment of Gram-negative multidrug-resistant strains (20). In addition, M $\beta$ Ls are encoded on genes linked to mobile elements, a condition that facilitates their spread among different bacterial species and genera (2). Presently, four distinct groups of M $\beta \mathrm{Ls}$ have been recognized: IMP, observed in Japan (18), VIM, originally detected in Italy (8), GIM, detected in Germany (3), and finally, SPM-1, first detected in São Paulo, Brazil (19). As result of variations in their aminoacid sequences, IMP and VIM enzymes are classified in a still growing number of subgroups (20).

Here, we report the occurrence, susceptibility patterns, and $\mathrm{M} \beta \mathrm{L}$ production of $P$. aeruginosa strains resistant to carbapenems isolated from hospitalized patients in Recife.

\section{Bacterial isolates}

Between November 1, 2002 and February 25, 2003, we isolated 48 strains of $P$. aeruginosa at a clinical laboratory in Recife, Brazil. Twenty-two isolates were from Hospital Português, a large hospital in Recife, and 26 isolates came from smaller hospitals: Hospital das Clínicas, 8, Hospital Unicordis, 4, Hospital São Marcos, 6, and Hospital Santa Joana, 4. All strains were recovered from hospitalized individuals, most were old (mean age $=71.4$ years) and debilitated with urinary tract infections or with respiratory problems undergoing ventilation. Only one isolate per patient was considered.

\section{Cultures identification and antibiograms}

Bacterial cultures were identified using conventional methods (7). Antibiotic susceptibility was determined by the disk diffusion method, according to NCCLS (10). Tests for polymixyn $\mathrm{B}$, however, were done by using a previously suggested protocol (5). The following antipseudomonas drugs were tested: ceftazidime, gentamicin, piperacillin, amikacin, aztreonam, cefepime, ciprofloxacin, levofloxacin, imipenem, meropenem, tobramicin, and polymixyn B (Oxoid Limited, Hampshire, England). Strains of $P$. aeruginosa presenting

*Corresponding Author. Mailing address: Rua Sete de Setembro, 508. 50050-030, Recife, PE, Brasil. E-mail: marcelo@ labmm.com.br 
intermediate or complete resistance to imipenem (inhibition zone $<16 \mathrm{~mm}$ ) were screened for $\mathrm{M} \beta \mathrm{L}$ production.

\section{Screening for $M \beta L$ production and $\beta$-lactamase gene identification}

Screening was done employing two double disk-synergy techniques. One of them (1) uses as M $\beta \mathrm{L}$ inhibitor blank disks impregnated with $2 \mu \mathrm{l}$ of undiluted 2-mercaptopropionic acid (2-MPA) solution (Aldrich Chemical Co, Milwaukee, USA) and as indicator, disks containing $30 \mu \mathrm{g}$ of ceftazidime (Oxoid). An enhanced zone of inhibition between the disks was indicative of $\mathrm{M} \beta \mathrm{L}$ production. The other technique (21) compares the sizes of the inhibition zones produced by two $10 \mu \mathrm{g}$ disks of imipenem (Oxoid), with and without $750 \mu \mathrm{g}$ of ethylenodiaminetetraacetic acid (EDTA); an increasing of at least $7 \mathrm{~mm}$ around the EDTAimipenem disk was recorded as a positive result.

The identification of $\mathrm{M} \beta \mathrm{L}$ coding genes was carried out by Patrice Nordmann (Hospital Bicêtre, Paris) using Polymerase chain reactions (15).
Among 48 isolates of $P$. aeruginosa obtained in this survey, $24(50 \%)$ were resistant to imipenem. Of these, $15(62.5 \%)$ were positive for $\mathrm{M} \beta \mathrm{L}$ production on the screening tests (Table 1). Both EDTA and 2-MPA enzyme inhibitors were equally efficient for neutralizing $\mathrm{M} \beta \mathrm{L}$ enzymes.

The imipenem-resistant strains were resistant to all drugs tested, except polymixyn $\mathrm{B}$, independently of $\mathrm{M} \beta \mathrm{L}$ production. This resistance pattern was similar to that found in Rio de Janeiro (12). Present data showed a higher percentage of M $\beta \mathrm{L}$-producing P. aeruginosa strains in Recife than that found in other Brazilian cities $(12,17)$. The multiplicity of antibiotic resistance gives to the imipenem-resistant strains a notable advantage for perpetuation and spreading in hospital settings, either carbapenems are or not being used, since they can be selected by a non-specific way (11).

All M $\beta$ L-producing strains were susceptible to aztreonam, while all except one of the nine non-M $\beta \mathrm{L}$-producers were resistant (Table 1). The incapacity of the metallo-enzymes to hydrolyze monobactams is well known $(11,14)$; it would be the first indication for the presence of M $\beta \mathrm{L}$-producing bacteria.

Table 1. Dates of recovery, origin, aztreonam susceptibility, and $\mathrm{M} \beta \mathrm{L}$ production by 24 imipenem-resistant $P$. aeruginosa strains isolated in hospitals in Recife, Brazil

\begin{tabular}{ccccccc}
\hline Isolate & Date* & Hospital & $\begin{array}{c}\text { Age } \\
\text { other patient }\end{array}$ & Isolate source & $\begin{array}{c}\text { Aztreonam } \\
\text { susceptibility }\end{array}$ & MßL production \\
\hline Pae 28 & $03 / 11 / 2002$ & Português & 75 & Urine & Susceptible & Positive \\
Pae 29 & $05 / 11 / 2002$ & Other & 76 & Urine & Susceptible & Positive \\
Pae 30 & $08 / 11 / 2002$ & Other & 75 & Blood & Susceptible & Positive \\
Pae 31 & $09 / 11 / 2002$ & Other & 85 & Urine & Resistant & Negative \\
Pae 32 & $14 / 11 / 2002$ & Português & 51 & BAL** & Susceptible & Positive \\
Pae 33 & $14 / 11 / 2002$ & Other & 91 & Urine & Resistant & Negative \\
Pae 34 & $29 / 11 / 2002$ & Other & 38 & BAL & Resistant & Negative \\
Pae 35 & $10 / 12 / 2002$ & Other & 75 & Urine & Susceptible & Positive \\
Pae 36 & $13 / 12 / 2002$ & Other & 73 & Urine & Susceptible & Positive \\
Pae 37 & $13 / 12 / 2002$ & Other & 76 & Sputum & Susceptible & Negative \\
Pae 38 & $26 / 12 / 2002$ & Português & 75 & Blood & Resistant & Negative \\
Pae 39 & $30 / 12 / 2002$ & Português & 49 & Urine & Susceptible & Positive \\
Pae 40 & $06 / 01 / 2003$ & Português & 75 & Tracheal*** & Susceptible & Positive \\
Pae 41 & $06 / 01 / 2003$ & Português & 84 & Urine & Susceptible & Positive \\
Pae 42 & $09 / 01 / 2003$ & Other & 84 & Urine & Susceptible & Positive \\
Pae 43 & $23 / 01 / 2003$ & Português & 43 & Tracheal & Susceptible & Positive \\
Pae 44 & $25 / 01 / 2003$ & Português & 70 & Tracheal & Resistant & Negative \\
Pae 45 & $27 / 01 / 2003$ & Português & 86 & Tracheal & Resistant & Negative \\
Pae 46 & $31 / 01 / 2003$ & Other & 91 & Urine & Resistant & Negative \\
Pae 47 & $10 / 02 / 2003$ & Other & 60 & Tracheal & Susceptible & Positive \\
Pae 49 & $15 / 02 / 2003$ & Other & 55 & Tracheal & Susceptible & Positive \\
Pae 50 & $17 / 02 / 2003$ & Português & 87 & Urine & Susceptible & Positive \\
Pae 51 & $18 / 02 / 2003$ & Other & 63 & Tracheal & Susceptible & Positive \\
Pae 52 & $23 / 02 / 2003$ & Português & 76 & Tracheal & Resistant & Negative \\
\hline
\end{tabular}

* Day/month/year; ** BAL, bronchi-alveolar lavage; *** Tracheal, tracheal aspirate. 
Studies done at Nordmann's laboratory in Paris, involving $11 \mathrm{M} \beta \mathrm{L}$-producing $P$. aeruginosa strains of the present series, selected at random, indicated that their carbapenemase is encoded on the gene blaspm-1, the same gene previously identified in the strain 48-1997, isolated in São Paulo (19). This strain, like the isolates from Recife, carries blaspm-1 on a plasmid. In addition, genetic analysis showed that upstream blaspm-1 there is a novel common region (CR4) comprising an open reading frame, orf495, which may be responsible for eventual mobilization and expression of the resistance gene (13).

The gene blaspm-1 is restricted so far to $P$. aeruginosa from Brazilian hospitals. Nevertheless, SPM-1 is not the only metallo-enzyme circulating in the country. Recently, a clinical strain of Acinetobacter baumannii producing an IMP-like M $\beta \mathrm{L}$ was detected in a Brazilian teaching hospital (6).

In Recife, drug-resistance constitutes a serious medical menace. Antibiotics are freely sold and for costs saving many patients are prematurely discharged from hospitals to complete their treatment at home. These practices would provide an unwished bridge between hospital and community for the dissemination of genes coding for multiple resistance to antibiotics.

\section{RESUMO}

\section{Produção de metalo- $\beta$-lactase de linhagens de Pseudomonas aeruginosa isoladas em Hospitais do Recife, PE, Brasil}

De 24 linhagens hospitalares de Pseudomonas aeruginosa provenientes de Recife, Brasil, 15 (62\%) produziram metalo- $\beta$ lactamase. Tais isolados foram resistentes às principais drogas antipseudomonas, exceto polimixina B e aztreonam. A enzima responsável pela resistência aos carbapanêmicos pertence à classe SPM-1 e o gene envolvido, blaspm-1, provavelmente é plasmidial.

Palavras-chave: Pseudomonas aeruginosa, multiresistência a drogas, metalo- $\beta$-lactamase

\section{REFERENCES}

1. Arakawa, Y.; Shibata, N.; Shibayama, K.; Kurokawa, H.; Yagi, T.; Fujiwara, H.; Masafumi, G. Convenient test for screening metallo- $\beta$-lactamaseproducing gram-negative bacteria by using thiol compounds. J. Clin. Microbiol., 38, 40-43, 2000.

2. Bennett, P.M. Integrons and gene cassettes: a genetic construction kit for bacteria. Antimicrob. Agents Chemother, 43, 1-4, 1999.

3. Castanheira, M.; Toleman, M.A.; Jones, R.N.; Schmidt, F.J.; Walsh, T.R. Molecular characterization of a $\beta$-lactamase gene, blaGIM-1, encoding a new subclass of metallo- $\beta$-lactamase. Antimicrob. Agents Chemother, 48 , 4654-4661, 2004.

4. Gales, A.C.; Menezes, L.C.; Silbert, S.; Sader, H.S. Dissemination in distinct Bazilian regions of an epidemic carbapenem-resistant Pseudomonas aeruginosa producing SPM metallo- $\beta$-lactamase. J. Antimicrob., 52, 699$702,2003$.
5. Gales, A.C.; Reis, A.O.; Jones, R.N. Contemporary assessment of antimicrobial susceptibility testing methods for polymixyn B and colistin: review of available interpretative criteria and quality control guidelines. $J$. Clin. Microbiol., 39, 183-190, 2001.

6. Gales, A.C.; Tognim, M.C.; Reis, A.O.; Jones, R.N.; Sader, H.S. Emergence of an IMP-like metallo-enzyme in an Acinetobacter baumannii clinical strain from a Brazilian teaching hospital. Diagn. Microbiol. Infect. Dis., 45, 77-79, 2003.

7. Kiska, D.L.; Gilligan, P.H. Pseudomonas, In: Murray, P.R.; Baron, E.J.; Pfaller, M.A.; Tenover, F.C.; Yolken, R.H. (eds.). Manual of Clinical Microbiology, $7^{\text {th }}$ ed. ASM Press. Washington, D.C., 1999, p. 516-526.

8. Lauretti, L.; Riccio, M.L.; Mazzario, A.; Cornaglia, G.; Amicosanti, G.; Fontana, R.; Rossoline, G.M. Cloning and characterization of blaVIM, a new integron-borne metallo- $\beta$-lacatamase gene from Pseudomonas aeruginosa clinical isolate. Antimicrob. Agents Chemother. 43, 15841590, 1999.

9. Lee, K.; Lim, J.B.; Yum, J.H.; Yong, D.; Chong, Y.; Kim, J.M.; Livermore, D.M. blaVIM- 2 cassette-containing novel integrons in metallo- $\beta$-lactamaseproducing Pseudomonas aeruginosa and Pseudomonas putida isolates disseminated in a Korean hospital. Antimicrob. Agents Chemother., 46, 1053-1058, 2002.

10. National Committee for Clinical Laboratory Standards. Perfomance standards for antimicrobial disk susceptibility tests. Approved standards M2A7. Seventh edition. Wayne, Pa. NCCLS, 2000.

11. Nordmann, P.; Poirel, L. Emerging carbapenemases in Gram-negative aerobes. Clin. Microbiol. Infect., 8, 321-331, 2002.

12. Pellegrino, F.L.P.C.; Teixeira, L.M.; Carvalho, M.G.S.; Nouér, S.A.; Teixeira, M.P.; Sampaio, J.L.M.; Freitas, A.A.; Ferreira, A.L.P.; Amorim, E.L.T.; Riley, L.W.; Moreira, B.M. Occurrence of a multidrug-resistant Pseudomonas aeruginosa clone in different hospitals in Rio de Janeiro, Brazil. J. Clin. Microbiol., 40, 2420-2424, 2002.

13. Poirel, L.; Magalhães, M.; Lopes, M.; Nordmann, P. Molecular analysis of metallo- $\beta$-lactamase gene blaspm-1 -surrounding sequences from disseminated Pseudomonas aeruginosa isolates in Recife, Brazil Antimicrob. Agents Chemother, 48, 1406-1409, 2004.

14. Poirel, L.; Naas, T.; Collet, L.; Bellais, S.; Cavallo, J.D.; Nordmann, P. Characterization of VIM-2, a carbapenem-hydrolyzing metallo- $\beta$ lactamase and its plasmid- and integron-borne gene from a Pseudomonas aeruginosa clinical isolate in France. Antimicrob. Agents Chemother. 44, 891-897, 2000

15. Poirel, L.; Nordmann, P. Accquired carbapenem-hydrolysing $\beta$-lactamases and their genetic support. Curr. Pharm. Biotechnol., 3, 117-127, 2002.

16. Rasmussen, B.A.; Bush, K. Carbapenem-hydrolyzing $\beta$-lactamases. Antimicrob. Agents Chemother, 41, 223-232, 1997.

17. Santos Filho, L.; Santos, I.B.; Assis, A.M.L.; Xavier, D.E. Determinação da produção de metalo- $\beta$-lactamases em amostras de Pseudomonas aeruginosa isoladas em João Pessoa, Paraíba. J. Bras. Patol. Med. Lab. 38, 291-296, 2002

18. Senda, K.; Arakawa, Y.; Nakashima, K.; Ito, H.; Ichiyama, S.; Shimokata, K.; Kato, N.; Ohta, M. Multifocal outbreaks of metallo- $\beta$-lactamasesproducing Pseudomonas aeruginosa resistant to broad-spectrum $\beta$-lactams, including carbapenems. Antimicrob. Agents Chemother., 40, 349-353, 1996.

19. Toleman, M.A.; Simm, A.M.; Murphy, T.A.; Gales, A.C.; Biedenbach, D.J.; Jones, R.M.; Walsh, T.R. Molecular characterization of SPM-1, a novel metallo- $\beta$-lacatamase isolated in Latin America: report from the SENTRY antimicrobial surveillance programme. J. Antimicrob. Chemother, 50, 673679, 2002.

20. Yan, J.J.; Hsueh, P.R.; Ko, W.C.; Luh, K.T.; Tsai, S.H.; Wu, H.M.; Wu, J.J. Metallo- $\beta$-lacatamase in clinical Pseudomonas isolates in Taiwan and identification of VIM-3, a novel variant of the VIM-2 enzyme. Antimicrob. Agents Chemother, 45, 2224-2228, 2001.

21. Yong, Y.; Lee, K.; Yum, J.H.; Shin, H.B.; Rossoline, G.M.; Chong, Y Imipenem-EDTA disk method for differentiation of metallo- $\beta$-lacatamaseproducing clinical isolates of Pseudomonas spp. and Acinetobacter spp. J. Clin. Microbiol. 40, 3798-3801, 2002. 